\title{
Breastfeeding based on Breastfeeding Self-efficacy and Social Support in Wonokromo Surabaya
}

\author{
Fauziyatun Nisa ${ }^{1,2}(\mathbb{D})$, Nyoman Damayanti ${ }^{3 *}(\mathbb{D})$ Fendy Suhariadi ${ }^{4}$, , Yasi Anggasari ${ }^{2}$, Ficky Erika Dewi $i^{2}$, Diyah Arini ${ }^{5}$ (D) \\ Firman Suryadi Rahman ${ }^{1}$ D \\ ${ }^{1}$ Doctoral Program of Public Health, Universitas Airlangga, Surabaya, Indonesia; ${ }^{2}$ Department of Nursing, Faculty of Nursing \\ and Midwifery, Universitas Nahdlatul Ulama, Central Jakarta, Surabaya, Indonesia; ${ }^{3}$ Department of Health Administration and \\ Policy, Faculty of Public Health, Universitas Airlangga, Surabaya, Indonesia; ${ }^{4}$ Department of Psychology, Faculty of Psychology, \\ Universitas Airlangga, Surabaya, Indonesia; ${ }^{5}$ Department of Nursing, Stikes Hang Tuah Surabaya, Surabaya, Indonesia
}

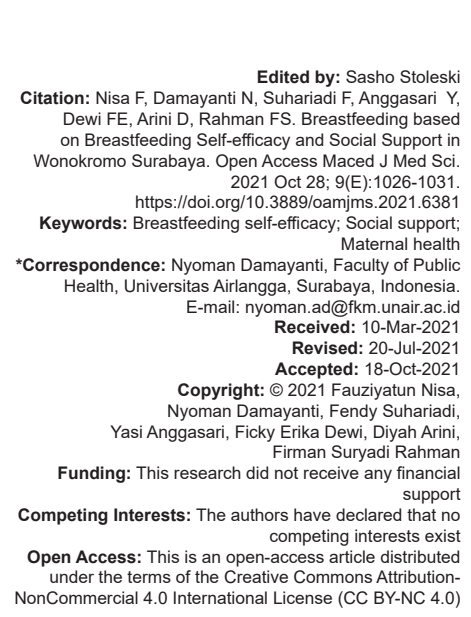

\section{Introduction}

Exclusive breastfeeding has great benefits for the optimization of child growth, development, and immune system. Although the benefits are clearly good, the prevalence of exclusive breastfeeding is still low. Failure of exclusive breastfeeding is one of the maternal problems. One of the reasons is because mothers still believe in the myth that when babies are often fussy and cry, they ask for additional food besides breast milk. Therefore, they give banana as additional food for the babies. The low mothers' self-confidence in breastfeeding and little social support in exclusive breastfeeding often become problems (Pratidina 2017 [1] in Rahayu, 2019) [2].

Self-efficacy has an influence in exclusive breastfeeding. Self-confidence called self-efficacy describes a person's belief in his ability to take a certain action in order to realize the expected or desired result (Bandura, 1997) [3]. Globally, the percentage of exclusive breastfeeding in Indonesia in 2017 was $35 \%$ and increased by $2.3 \%$ in 2018 . However, it is still far from the target set by the WHO, which is $50 \%$. In East Java, exclusive breastfeeding in 2017 was $75.7 \%$ and it decreased quite a lot in 2018 which was $35.65 \%$. The achievement of exclusive breastfeeding in East Java province is still below the target set by the Indonesian Ministry of Health, which is $80 \%$ (Surabaya Health Office, 2018). In Wonokromo, the coverage of exclusive breastfeeding decreased in 2018 by $10.61 \%$ from $68.68 \%$ in 2017.

Based on monitoring data of nutritional status in Indonesia in 2017, exclusive breastfeeding for 6 months in Indonesia is still very low and still far from the target of exclusive breastfeeding set by the Ministry of Health (Ministry of Health, 2017 in Rahayu, 2018 [2]). In Magetan in 2017, there were 111 toddlers with malnutrition, consisting of 52 boys and 59 girls. Until 2020, the number of toddlers experienced malnutrition has increased to 230 .

Based on the results of data in early January 2020 at one of the Integrated Healthcare Center in Wonokromo Surabaya, among 40 mothers, only 18 (45\%) of them able to provide exclusive breastfeeding without additional 
food, while the other $22(55 \%)$ were unable to breastfeed without additional food.

The low level of exclusive breastfeeding in Indonesia is caused by internal and external factors. Internal factors include the low knowledge and attitudes of mothers toward breastfeeding (Breastfeeding Self Efficacy), while the external factors are family, community, health and government support, incessant promotion of formula milk, social factors, and social support [4]. The nutritional content of breast milk plays an important role in the growth and development of the baby. There are benefits of exclusive breastfeeding for babies and mothers, including protection against the risk of infection in infants and optimizing children's cognitive development. In addition, it is also useful to reduce the risk of breast and ovarian cancer on mothers. Babies who are not exclusively breastfed can be at risk of dying from diarrhea or pneumonia [5].

One of the factors that determine the success of exclusive breastfeeding is the condition of the mother, such as the mother's confidence in breastfeeding [6]. According to Bandura theory (1997) [3], self-efficacy affects exclusive breastfeeding. Self-confidence called self-efficacy describes a person belief in his ability to take actions in order to realize the expected or desired results. Breastfeeding Self-Efficacy (BSE) is a mother belief in her ability to breastfeed her baby and estimation to breastfeed or not, how much effort is spent, the ability to increase or not, and how to respond emotionally to breastfeeding difficulties [7].

In this case, the important role of health workers is to increase mother's motivation and provide social support such as sharing experiences in breastfeeding, providing information, assistance, and giving appreciation.

\section{Methods}

The research was conducted through analytical design using a cross-sectional approach by observing the independent variable and the dependent variable only once at the same time. The population in this research was 112 mothers who had babies aged 6-12 months in Wonokromo District, Surabaya. Among the population, 106 mothers were chosen as research respondents through a simple random sampling technique with probability sampling. Meanwhile, the research instrument used was questionnaire.

Data from the questionnaire were used to determine the level of BSE, social support, and breastfeeding in Wonokromo, Surabaya. Data were then processed by cross-tabulation and Chi-square test using SPSS for windows.

\section{Results}

\section{General data}

General data present the respondents characteristics, including the education level, occupation, and experience of mothers who breastfeed their babies.

\section{education}

\section{Respondents characteristics based on}

Based on Table 1, it is known that most of the 106 respondents $(75.0 \%)$ had a basic education (primary school/High School).

Table 1: Distribution of respondents based on education level in Wonokromo, Surabaya

\begin{tabular}{lll}
\hline Education Level & Frequency $(\mathrm{n})$ & Percentage \\
\hline Primary School & 80 & 75.0 \\
High School & 26 & 25.0 \\
College & 0 & 0 \\
Total & 106 & 100.0 \\
\hline Source: Primary Data, July 2020. & &
\end{tabular}

\section{Respondent characteristics of based on job}

Based on Table 2, it is known that among 106 respondents, most of them (66\%) were unemployed.

Table 2: Distribution of respondents based on Occupation in Wonokromo, Surabaya

\begin{tabular}{lll}
\hline Job & Frequency $(\mathrm{n})$ & Percentage \\
\hline unemployed & 70 & 66.0 \\
Employed & 36 & 34.0 \\
Total & 106 & 100.0 \\
\hline Source: Primary Data, July 2020. & &
\end{tabular}

Respondent characteristics based on breastfeeding experiences

Based on Table 3, it is known that among 106 respondents, most of them $(47.2 \%)$ had their first breastfeeding experience.

Table 3: Distribution of respondents based on breastfeeding experiences in Wonokromo, Surabaya

\begin{tabular}{lll}
\hline Knowledge Level & Frequency $(\mathrm{n})$ & Percentage \\
\hline First Child & 50 & 47.2 \\
Second Child & 44 & 41.5 \\
Third Child & 12 & 11.3 \\
Total & 106 & 100.0 \\
\hline Source: Primary Data & &
\end{tabular}

\section{Particular data}

Particular data describes the respondent characteristics based on the level of BSE, the level of social support, and breastfeeding in Wonokromo, Surabaya. of BSE

Respondent characteristics based on the level

Based on Table 4, 36 respondents $(77.4 \%)$ had a poor level of BSE. 
Table 4: Distribution of respondents based on BSE Level in Wonokromo, Surabaya

\begin{tabular}{lll}
\hline BSE & Frequency $(\mathrm{n})$ & Percentage \\
\hline Good & 24 & 22.6 \\
Low & 82 & 77.4 \\
Total & 106 & 100.0 \\
\hline Source: Primary Data, July 2020, BSE: Breastfeeding self efficacy.
\end{tabular}

Respondent characteristics based on the level of social support

Based on Table 5, 106 respondents (51.9\%) had a low level of social support.

Table 5: Distribution of Respondents Based on the Level of Social Support in Wonokromo, Surabaya

\begin{tabular}{lll}
\hline Social Support & Frequency $(\mathrm{n})$ & Presentage \\
\hline High & 24 & 22.6 \\
Middle & 27 & 25.5 \\
Low & 55 & 51.9 \\
Total & 106 & 100.0 \\
\hline Source: Primary Data, July 2020. & &
\end{tabular}

\section{breastfeeding}

Respondent characteristics based on the

Based on Table 6, 36 respondents, which is $(66.9 \%)$ did not provide exclusive breastfeeding, they gave additional food to their babies during the first 6 months.

Table 6: Distribution of Respondents Based on the Breastfeeding in Wonokromo, Surabaya

\begin{tabular}{lll}
\hline Breastfeeding & Frequency $(\mathrm{n})$ & Percentage \\
\hline Exclusive & 35 & 33.1 \\
Not Exclusive & 71 & 66.9 \\
Total & 106 & 100.0 \\
\hline Source: Primary Data, July 2020. & &
\end{tabular}

The relationship between BSE and breastfeeding in Wonokromo, Surabaya

Based on Table 7, among 106 respondents, there were 24 respondents, who had good BSE (100\%), provided exclusive breastfeeding for their babies. Meanwhile, 82 respondents had poor BSE, almost all of them (89\%) did not exclusively breastfeed.

Table 7: Cross-tabulation of the relationship between BSE and breastfeeding in Wonokromo, Surabaya

\begin{tabular}{|c|c|c|c|c|c|c|}
\hline \multirow[t]{3}{*}{ Breast-feeding Self-Efficacy } & \multicolumn{4}{|c|}{ Breastfeeding } & \multicolumn{2}{|c|}{ Total } \\
\hline & \multicolumn{2}{|c|}{ Exclusive } & \multicolumn{2}{|c|}{ Not exclusive } & \multirow[t]{2}{*}{$\mathrm{n}$} & \multirow[t]{2}{*}{$\%$} \\
\hline & $\mathrm{n}$ & $\%$ & $n$ & $\%$ & & \\
\hline Good & 24 & 100 & 0 & 0 & 24 & 100 \\
\hline low & 11 & 11 & 71 & 89 & 82 & 100 \\
\hline Total & 35 & 33.1 & 75 & 66.9 & 106 & 100 \\
\hline
\end{tabular}

The statistical test used in this study is the Chi-square test and the calculation of SPSS for windows with a significance level of $\alpha-0.05$. The p-value obtained was $\rho-0.000<\alpha-0.05$, so $\mathrm{HO}$ is rejected, indicating that there was a relationship between BSE and breastfeeding in the Wonokromo, Surabaya.
The relationship between social support and breastfeeding in Wonokromo, Surabaya

Based on Table 8, there were 24 respondents, who had high social support, gave exclusive breastfeeding (100\%). Among the 27 respondents who have considerable social support (70.4\%) did not provide exclusive breastfeeding. Meanwhile, among 55 respondents who had low social support (94.5\%) did not exclusively breastfeed.

Table 8: Cross-tabulation of the relationship between social support and breastfeeding in Wonokromo, Surabaya

\begin{tabular}{|c|c|c|c|c|c|c|}
\hline \multirow{3}{*}{ Social Support } & \multicolumn{4}{|c|}{ Breastfeeding Provision } & \multicolumn{2}{|c|}{ Total } \\
\hline & \multicolumn{2}{|c|}{ Exclusive } & \multicolumn{2}{|c|}{ Not exclusive } & & \\
\hline & $\mathrm{n}$ & $\%$ & $\mathrm{n}$ & $\%$ & $n$ & $\%$ \\
\hline High & 24 & 100 & 0 & 0 & 24 & 100 \\
\hline Middle & 8 & 29.6 & 19 & 70.4 & 27 & 100 \\
\hline Low & 3 & 5.5 & 52 & 94.5 & 55 & 100 \\
\hline Total & 35 & 33.1 & 71 & 66.9 & 106 & 100 \\
\hline
\end{tabular}

The statistical test used in this research was the Chi-square test and the calculation of SPSS for windows is carried out with a significance level of $\alpha-0.05$. The $p$-value obtained was $\rho-0.000<\alpha-0.05$, so $\mathrm{HO}$ is rejected, indicating there was a relationship between social support and breastfeeding provision in Wonokromo, Surabaya.

\section{Discussion}

\section{BSE}

Based on Table 4, almost all of 106 respondents $(77.4 \%)$ had a low level of BSE. Almost all mothers had low confidence that mothers can fully breastfeed their babies. Based on the questionnaire data, mothers could not solve problems during breastfeeding as well as had low experience and satisfaction in giving exclusive breastfeeding.

According to our research view, the impact of self-efficacy is individual responses including behavioral choice, effort and persistence, perspective, and emotional reactions. Individual response will determine the behavior taken, from initiating breastfeeding to active breastfeeding until maintaining consistent breastfeeding. According to Dennis and McQueen (2010) [8], high BSE shows a high sense of confidence in breastfeeding mother. Therefore, if a mother has a high level of BSE, exclusive breastfeeding will be maintained.

Based on Table 1, almost the entirely of 106 respondents (75.0\%) had basic education (Primary School/Junior High School). Mothers who had basic education did not have enough knowledge and, did not have the motivation to seek information related to how to motivate themselves to solve the problems in breastfeeding, such as finding sources of information 
on proper and correct breastfeeding techniques, so that they are able to constantly breastfeed their babies. According to Damayanti (2010) [4], many mothers still do not understand the breastfeeding process and benefits. Adequate knowledge will increase the chances of success in breastfeeding the baby.

Based on Table 3, almost half of the mothers $(47.2 \%)$ had breastfeeding experience for the $1^{\text {st }}$ time. Another factor that affects BSE is the mother's experience of giving exclusive breastfeeding. In the questionnaire, the mother said that they were not satisfied with the experience of breastfeeding her baby. Whereas, the experience of mothers in exclusive breastfeeding greatly affects the success rate of BSE. According to Dennis (2010) [7], if the level of mother satisfaction in terms of breastfeeding experience is high, mother motivation to always provide exclusive breastfeeding to the baby is also high.

\section{Social support}

Soetjiningsih (2010) [9], suggest that social support from environment around the mother has a major role in the success of breastfeeding. The most influencal social support comes from the closest person to the mother, the closest person is the husband. Husband's support for his wife can be done by helping his wife in taking care of the baby, for example when the mother breastfeeds her baby, the father does not only sleep through the night [10].

Based on Table 5, it is found that among the 106 respondents, most of them $(51.9 \%)$ had low social support. When a mother does not feel comfortable in their environment which does not provide a solution or information about problem in breastfeeding, the mother will feel less confident in giving exclusive breastfeeding, since there is no support from the around environment, especially the husband and the mother's closest family. Social support is information or feedback from others that shows that someone is cared for, respected, given an award for breastfeeding exclusively, given comfort, provided by the source of information, and had a helpful relationship with, as well as a positive assessment in the individual in facing problems.

Social support is a key indicator of a mother's decision to breastfeed and strongly give a positive effect on breastfeeding rates. Social support is a resource provided by others as a mechanism that impacts health. Lack of social support and the existence of norms and myths in society can cause mothers prefer not to breastfeed and provide additional formula milk to their children. Findings from previous studies on the effect of social support on breastfeeding are mixed. In a qualitative study, it was reported that women with high social support were more successful in breastfeeding. Other studies reported that social relationships and friendship, social support, women's knowledge about the benefits of breastfeeding, and comfort are some of the driving factors of breastfeeding.

\section{Breastfeeding}

Based on Table 6, it shows that among 106 respondents, most of the respondents $(66.9 \%)$ did not provide exclusive breastfeeding. The mothers in Wonokromo were not confident in their ability to provide exclusive breastfeeding. In addition, most of them rarely attend health counseling from Integrated Healthcare Center cadres so that there was a lack of information on the importance of health, especially exclusive breastfeeding for infants aged 0-6 months old. Whereas, breast milk is a complex biological element that contains all the nutrients needed for the baby's body [11].

Based on Table 1, among 106 respondents, most of them $(75.0 \%)$ had basic education. The education level is a factor that affects exclusive breastfeeding because the higher mother's education level, the more mother gets the knowledge of the importance of exclusive breastfeeding. Therefore, if a mother knows the importance of exclusive breastfeeding, the mother will exclusively breastfeed her baby. Hence, the level of education will affect the knowledge and understanding of mothers to be more responsive to information on the importance of exclusive breastfeeding for their babies. According to Maryunani (2012) [11], the level of education, occupation, and knowledge are all factors in exclusive breastfeeding. The higher the level of education of the mother, the easier it is to get information so that it creates something good. On the other hand, a mother with less education will hinder her understanding with information about new topics.

Based on Table 2, it shows that among 106 respondents, most of them $(66 \%)$ were mothers who did not work. Mothers who do not work will be busy taking care of the household and time to find information about the importance of breastfeeding is low and the scope of mothers who do not work get information only from their environment. In Wonokromo Surabaya, mothers prefer to provide additional formula milk. This is due to the lack of information on the importance of exclusive breastfeeding for babies. According to Soetjiningsih (2010) [9], promotion of formula milk is not only found in cities, even various electronic and printed media fully provide information about breastfeeding substitutes.

\section{The relationship between BSE and breastfeeding in Wonokromo, Surabaya}

Based on the results of research using the Chi-square test and calculation using SPSS for windows with significance level of $\alpha-0.05$, the results obtained was $\rho-0.000<\alpha-0.05$, so $\mathrm{HO}$ is rejected, indicating that there was a relationship between BSE and breastfeeding in Wonokromo Surabaya.

Mother's belief in the success of giving exclusive breastfeeding will help determine how much effort is put to achieve goals, build self-motivation, and whether the mother's actions can be continued if 
there are difficulties, and take positive action in facing these difficulties. If the mother is determined to provide exclusive breastfeeding, it will increase the level of BSE in breastfeeding mothers. On the other hand, if the mother's confidence is low, the level of breastfeeding for the baby will be low as well. This proves that there was a relationship between BSE and exclusive breastfeeding.

Mothers with first breastfeeding experience are often very sensitive to the baby's condition. So that they are easy to be provoked by various negative assumptions such as babies will not be full enough if they only get breast milk. Therefore babies still cry and are fussy when only given breast milk. Mothers with high expectations about baby care but not supported by enough knowledge will follow the recommendations or suggestions from people around the mother without looking for sources of information and knowledge first. Therefore, the education level of a mother will affect the level of mother's confidence in breastfeeding without additional food for her baby.

According to Pratidina (2017) [1], one of the factors that determine exclusive breastfeeding is the mother condition, such as the belief in giving exclusive breastfeeding (BSE), the experience in breastfeeding, and the level of knowledge about breastfeeding. These factors will affect a mother's decision to choose to breastfeed or not.

\section{The relationship between social support and breastfeeding in Wonokromo, Surabaya}

Based on the research results using the Chi-square test and calculation using SPSS for windows with significance level determined $(\alpha-0.05)$, the results obtained $\rho-0.000<\alpha-0.05$, thus $\mathrm{H} 0$ is rejected, indicating that there was a relationship between social support and exclusive breastfeeding in Wonokromo Village, Surabaya.

Social support can be obtained from mothers' closest people, including husbands, parents, family, friends, and people in the mother's environment. Social support is very influential in breastfeeding because when a mother feels valued, given help and support, given information about breastfeeding, the mother will be more confident to breastfeed without additional foods. Mothers who do not work tend to have a low level of understanding about breast milk. This is because the mother only gets information from the surrounding environment. The findings in the local community stated that people still believe in the myth that when a baby is still fussy and crying, it means that the mother's milk for the baby is still lacking. So that the mother must provide additional food such as soft bananas for the baby. This is when the mother is easily provoked by the myth without looking for the correct information, then the mother will do according to what has been suggested by people around. Hopefully, the mother can provide the best care for her baby.
This concurs with the previous study on the effect of social support on breastfeeding. In a qualitative study, it was stated that women with high social support were more successful in breastfeeding. Other studies described that social relationships and friendship, social support, knowledge about the benefits of breastfeeding, and comfort are several driving factors of breastfeeding.

BSE is still low and breastfeeding is not effective yet often occurs in mothers who have never had breastfeeding experience before. Mothers with the first experience of breastfeeding are often very sensitive to everything related to the condition of their babies, so they are easily provoked by various negative assumptions such as the baby will not be full enough if he only gets breast milk, especially at the beginning of the postpartum period, mothers only produce colostrum in small amounts or have not even released breast milk. Mothers with high expectations about optimal baby care, but not supported by adequate knowledge and support can cause mothers to fall into stressful conditions during the postpartum period (postpartum blues). Mothers who experience postpartum blues symptoms at the beginning of the postpartum period have a tendency to stop breastfeeding early, experience various difficulties in breastfeeding and have low BSE [8].

\section{Conclusions and Recommendation}

\section{Conclusion}

Based on the description that has been stated, the following conclusions can be described:

1. Almost all mothers who have babies aged 6-12 months old in Wonokromo Surabaya have a low level of BSE

2. Mothers who have babies aged 6-12 months in Wonokromo Surabaya mostly get low social support

3. There is a relationship between BSE and breastfeeding in Wonokromo Surabaya

4. There is a relationship between social support and breastfeeding in Wonokromo, Surabaya.

\section{Recommendation}

From the conclusions obtained from the research results and discussion, the research suggestions are as follows:

1. For the next researcher, It is necessary to do research in a broader scope with other variables that affect exclusive breastfeeding and by using the newest book references

2. For Respondents, It is expected that respondents who do not provide exclusive breastfeeding to their babies should shift to 
breastfeed exclusively. Because the frequency of the baby's suction also affects the milk production. The more frequent the mother breastfeed, the more breastmilk is produced and the breastmilk will come out easily

3. For the Community, It is hoped that the community provides full support, assistance, and information to mothers who provide exclusive breastfeeding because the support from the community also encourages and motivates the mothers to be more confidence in giving exclusive breastfeeding to their babies.

\section{References}

1. Pratidina FA. Breastfeeding self efficacy pada ibu post partum di rs pku muhammadiyah gombong. J Kesehatan. 2017.

AQ7 2. Dwi R. Hubungan Breastfeeding Self Efficacy Dengan Keberhasilan Pemberian ASI Eksklusif. J IImu Kesehatan. 2018;7(1):247-52. https://doi.org/10.52643/jbik.v11i1.1349.
3. Bandura A. Self-Efficacy; the Exercise of Control. New York: W. H. Freeman and Company; 2007.

4. Damayanti D. Asyiknya Minum ASI. Jakarta: Gramedia Pustaka Utama; 2010

5. Prasetyono DS. Buku Pintar ASI Eksklusif. Yogyakarta: Diva Press; 2012.

6. Pratidina A, FIAN. Breasfeeding Self Efficacy Pada lbu Post Partum at RS PKU Muhammadiyah Gomong; 2017.

7. Dennis CL. The breastfeeding self efficacy scale: Psychometric assesment of the short form. J Obstet Gynecol Neonatal Nurs. 2010;32(6):734-44.

PMid: 14649593

8. Dennis CL, McQueen K. The relationship between infant-feeding outcomes and postpartum depression: A qualitative systematic review. Pediatrics. 2009;123(4):e736-51. https://doi. org/10.1542/peds.2008-1629.

PMid: 19336362

9. Soetjiningsih S. Indonesia Menyusui. Badan Penerbit IDAI; 2010.

10. Ingela S. The Experienceof Social Support in Patients Suffering from Treatment Refractory Depression a Pilot Study Archieves of Psyciatric Nurshing. Philadelpia, PA: Lippircot; 1999.

11. Maryunani A. Inisiasi Menyusui Dini ASI Eksklusif dan Manajemen Laktassi. Jakarta: TIM; 2012.

Author Queries???

AQ7: Kindly provide in English language 